\title{
PEMIKIRAN AL-GHAZALI TENTANG MEKANISME PASAR DAN PENETAPAN HARGA
}

\author{
Indra Hidayatullah \\ Institut Agama Islam Syarifuddin Lumajang \\ e-mail: indra_hidayatullah@yahoo.co.id
}

\begin{abstract}
Market, country, individual and society have always been a hot topic of economic discussion. The market is one of the economic driver in a country that has an overall success can be seen from the market mechanism that carried out. The economic real good of the country is driven by market mechanisms that uphold freedom and justice. Hence, the market is free and impartial. The operation of a market will be determined by several factors such as price, demand and supply, distribution and specialization of workers. In case those factors run according to the rules in the country, the economy in the country will be stable certainly. The market is a natural mechanism for exchanging goods and services and it has been going on since the beginning of human changes. Islam places the market in an important position in the economy. The practices during the time of Rasulullah SAW and al-Khulafā al-Rāshidūn showed a large market role. Rasulullah SAW really appreciated the price that was formed by the market as a fair price. In the history of economics world, several Islamic economies have emerged that raise scientific themes about market mechanisms, such as the thought of al-Ghazali. The book Ihya' 'Ulum al-Din is one of his great works and one of the major works in the Islamic library. Although there are several other works of al-Ghazali in various fields of economics but the essence of his entire essay include his discussion of economics is the book Ihya' 'Ulum al-Din. It provides features and characteristics of Islam in various sciences (moral, tasawwuf, economic and other), be one source of economics. Al-Ghazali, an Islamic scholar has socio-economics thought, rooted in a concept called "the socioeconomic welfare function". The concept based of all his works is the concept of maslahah or social welfare, which is the concept that covers all human activities and makes close relations between individual and society.
\end{abstract}

Keywords: al-Ghazali thinking, market mechanism, price determination

\section{Pendahuluan}

Allah SWT menciptkan manusia sebagai makhluk sosial. Di dalam kehidupan bermasyarakat manusia selalu berhubungan satu dengan yang lainya disadari atau tidak untuk mencukupi kebutuhan hidupnya. Adanya kebutuhan hidup manusia merupakan sesuatu alami (fitrah) yang dianugerahkan Allah untuk memungkinkan manusia bertahan hidup. Fitrah tersebut muncul sebagai potensi kehidupan yang mendorong manusia untuk memenuhi kebutuhan, termasuk yang berkaitan dengan kebutuhan ekonomi. ${ }^{1}$

Pasar, negara, individu dan masyarakat selalu menjadi topik pembahasan yang hangat dalam ilmu ekonomi. Pasar merupakan salah satu penggerak roda perekonomian dalam suatu negara yang secara umum keberhasilannya bisa dilihat dari mekanisme pasar yang dijalankan.

\footnotetext{
${ }^{1}$ Sholahuddin, Asas-Asas Ekonomi Islam (Jakarta: raja Grafindo Persada, 2007), 13.
} 
Ekonomi negara yang baik itu digerakkan oleh mekanisme pasar yang menjunjung kebebasan dan keadilan, karenanya pasar itu bebas dan tidak berpihak.

Berjalannya sebuah pasar akan ditentukan oleh beberapa faktor, pertama tentang harga, permintaan dan penawaran, distribusi dan spesialisasi pekerja, yang mana ketika faktor di atas berjalan sesuai aturan yang ada dalam negara tersebut, maka bisa dipastikan perekonomian dalam negara tersebut akan stabil.

Dalam penentuan harga suatu barang di suatu kota misalnya, akan tergantung oleh berkembang atau tidaknya populasi dalam daerah tersebut, jika populasi meningkat maka dengan sendirinya pengadaan akan barang-barang kebutuhan pokok mendapat prioritas, sehingga penawaran meningkat dan berakibat pada penurunan harga barang tersebut. Sedangkan untuk barang mewah, permintaannya akan meningkat, sejalan dengan perkembangan kota dan berubahnya gaya hidup. Akibatnya harga barang mewah tersebut pun menjadi naik. $^{2}$

Pengaruh naik turunnya penawaran terhadap harga tergantung pada ketersediaan barang, karena ketika barang-barang yang tersedia sedikit, maka harga-harga akan naik. Namun, bila jarak antara kota dekat dan aman, maka akan banyak barang yang diimpor sehingga ketersediaan barang akan melimpah dan harga-harga akan turun. ${ }^{3}$

Islam adalah satu-satunya agama yang mengemukakan prinsip-prinsip yang meliputi semua segi kehidupan manusia, tidak hanya membicarakan tentang nilai-nilai ekonomi. Islam telah menamkan kerangka kerja yang luas berdasarkan atas kesempatan berekonomi yang sama dan adil untuk mengarakan mereka ke arah kehidupan ekonomi yang seimbang. ${ }^{4}$

Dalam perekonomian, pasar berperan sangat penting khususnya dalam sistem ekonomi bebas atau liberal. Pasar yang berperan mempertemukan produsen (yang memproduksi dan menawarkan barang) dan konsumen (yang menentukan jumlah dan jenis barang atau komoditas yang dikehendakinya). Konsumen sangat menentukan kedudukan pasar, sebab konsumenlah yang berperan untuk menentukan lalu lintas barang dan jasa. ${ }^{5}$

Pasar adalah sebuah mekanisme pertukaran barang dan jasa yang alamiah dan telah berlangsung sejak perubahan awal manusia. Islam menempatkan pasar pada kedudukan yang sangat penting pada perekonomian. Praktik pada masa Rasulullah SAW menunjukan adanya peranan pasar yang besar. Rasulallah SAW sangat menghargai harga yang dibentuk oleh pasar sebagai harga yang adil. ${ }^{6}$

Penghargaan ajaran Islam terhadap mekanisme pasar berangkat dari ketentuan Allah SWT bahwa perniagaan harus dilakukan secara baik dengan rasa suka sama suka ('an tarädin min kum atau mutual goodwill). Agar mekanisme pasar berjalan dengan baik dan memberikan mutual goodwill bagi para pelakunya, maka mutlak nilai-nilai moralitas harus ditegakkan. Secara khusus nilai moralitas yang mendapat perhatian penting dalam pasar adalah persaingan yang sehat (fairplay), kejujuran (honesty), keterbukaan (transparancy) dan keadilan (justice). ${ }^{7}$

\footnotetext{
${ }^{2}$ P3EI, Ekonomi Islam (Jakarta: Rajawali Press, 2012), 310-311.

${ }^{3}$ Ibid.

4 Abdul Mannan, Teori dan Praktek Ekonomi Islam, terj. M. Nastangin (Yogyakarta: PT Dana Bakti Wakaf, 1997), 149.

${ }^{5}$ Suhrawardi K. Lubis, Hukum Ekonomi Islam (Jakarta: Sinar Grafika, 2000), 21.

${ }^{6}$ Pusat Pengkajian dan Pengembangan Ekonomi Islam UII, Ekonomi Islam (Jakarta: Rajawali Press, 2009 ), 301.

${ }^{7}$ Hendrieanto, Pengantar Ekonomi Mikro Islami (Yogyakarta: Ekonisia, 2003), 270.
} 


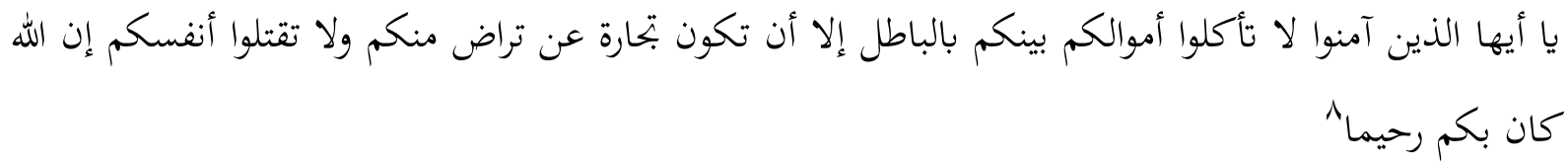

"Hai orang-orang yang beriman, janganlah kamu saling memakan harta sesamamu dengan jalan yang batil, kecuali dengan jalan perniagaan yang Berlaku dengan suka sama-suka di antara kamu. dan janganlah kamu membunuh dirimu, Sesungguhnya Allah adalah Maha Penyayang kepadamu". 9

Islam sangat menghargai pasar sebagai wahana alokasi dan distribusi sumber daya ekonomi. Tetapi, dalam ajaran Islam pasar ditempatkan pada posisi proporsional, berbeda dengan pandangan kapitalis maupun sosialisme yang ektrem. Ajaran Islam sangat menghargai pasar sebagai tempat perniagaan yang halal (sah) dan tayyib (baik), sehingga secara umum merupakan mekanisme perniagaan yang paling ideal. Penghargaan tinggi ini tidak bersifat normatif, tetapi juga telah dibuktikan dalam sejarah panjang kehidupan ekonomi masyarakat Islam klasik. Rasulullah sendiri adalah seoarang pelaku pasar yang aktif, demikian pula para sahabat. ${ }^{10}$

Teori atau pemikiran-pemikiran ekonomi Islam yang dikontribusikan oleh para sarjanasarjana muslim karya-karya mereka sangat monumental sekaligus berbobot, karena mereka mendasarkan karyanya pada argumentasi religius dan sekaligus intelektual yang sama-sama kuat juga didukung oleh fakta empiris dan dikaji dengan kajian komparatif di zaman tersebut. Dalam ekonomi Islam, ekonomi didefinisikan sebagai suatu cara untuk memenuhi kebutuhan hidup seseorang atau lebih (bersama) dengan cara yang halal dan tayyib serta berlaku adil dalam usaha yang dilakukannya dengan prinsip saling ridha dan menguntungkan. ${ }^{11}$

Al-Ghazali dikenal sebagai sosok intelektual multidimensi dengan penguasaan ilmu multidisiplin. Hampir semua aspek keagamaan dikajinya secara mendalam, termasuk persoalam ekonomi yang sesuai dengan aturan Islam. Al-Ghazali juga dikenal sebagai sosok ilmuan dan penulis yang sangat produktif, beliau dijuluki dengan hujjah al-isläm. Banyak pemikir barat yang terpengaruh dangan karya beliau. ${ }^{12}$

Kitab Ihya- 'Ulum al-Din salah satu karya besar dari beliau dan salah satu karya besar dalam perpustakaan Islam. Meskipun ada beberapa karangan al-Ghazali yang lain dalam berabagai bidang ekonomi, namun yang menjadi intisari dari seluruh karangan beliau termasuk bahasannya tentang ekonomi adalah kitab Ihya' 'Ulum al-Din yang memberikan corak dan karekter Islam dalam berbagai ilmu (akhlak, tasawuf, ekonomi dan lain-lain), sehingga menjadi salah satu sumber ilmu ekonomi. ${ }^{13}$

Al-Ghazali seorang ulama Islam dalam pemikirannya tentang sosio ekonomi berakar dari konsep yang beliau sebut dengan "fungsi kesejahteraan sosial ekonomi". Konsep yang menjadi pangkal tolak seluruh karyanya adalah konsep maṣlahah atau kesejahteraan sosial,

\footnotetext{
${ }^{8}$ al-Quran, 4: 29.

${ }^{9}$ Departemen Agama RI, al-Qur'an dan Terjemahan (Solo: PT Tiga Serangkai, 2009), 83.

${ }^{10}$ Hendrianto, Pengantar Ekonomi Mikro Islam, 314.

${ }^{11}$ Mohamad Hidayat, an Introduction to The Sharia Economic (Jakarta: Zikrul Hakim, 2010), 28.

${ }^{12}$ Nur Chamid, Jejak Langkah Sejarah Pemikiran Ekonomi (Yogyakarta: Pustaka Pelajar, 2010), 219.

${ }^{13}$ Ibid.
} 
yakni sebuah konsep yang mencangkup semua aktifitas manusia dan membuat berhubungan erat antara individu dan masyarakat. ${ }^{14}$ Menurutnya, kesejahteraan (mașlahah) dari suatu masyarakat tergantung kepada pemeliharaan lima tujuan dasar, sehingga dapat diketahui apakah aktivitas muamalah yang dijalankan sudah sesuai dengan prinsip syariah atau tidak.

Tujuan utama syariah adalah untuk mendorang kesejahteraan manusia yang terletak pada perlindungan kepada keimanan (al-dīn), jiwa (al-nafs), akal (al-'aql), keturunan (alnasl) dan harta (al-mal) mereka. Apa saja yang menjamin terlindungnya lima perkara ini adalah memenuhi kepentingan publik dan dianjurkan, dan apa saja yang menciderai lima perkara ini adalah melawan kepentingan publik yang harus dibuang. ${ }^{15}$

\section{Biografi Al-Ghazali}

Al-Ghazali dilahirkan pada abad ke-5 $\mathrm{H}$ tepatnya tahun $450 \mathrm{H}$ bertepatan dengan tahun $1058 \mathrm{M}^{16}$ di Ghazalah sebuah kampung kecil di pinggir kota kecil bernama Tusi ${ }^{17}$ (Sekarang Meshed) yang merupakan kota kedua di Khurasan (Sekarang Iran) setelah Naysabur salah satu kota di Khurasan ${ }^{18}$ Iran yang didominaasi oleh mayoritas Islam Sunni dan sebagian kecil Islam Syiah serta penduduk yang menganut agama Kristen. ${ }^{19}$ Nama lengkapnya adalah Abu Hamid Muhammad Ibn Muhammad Ibn Ahmad Al-Ghazali al-Tusi. Ia mempunyai banyak gelar kehormatan yang belum pernah diberikan pada pemikir-pemikir sebelumnya.

Pada umumnya terdapat perbedaan pendapat mengenai gelar yang diberikan kepada alGhazali. Sebagaian golongan menggunakan gelar "al-Ghazali" dan sebagian yang lain menggunakan gelar "al-Ghazzali”. Perbedaan ini timbul disebabkan mereka merujuk pada kampung kelahiran al-Ghazali yaitu Ghazalah dan yang lain merujuk pada pekerjaan orang tuanya sebagai tukang pintal benang atau ghazzal. ${ }^{20}$ Tapi alasan yang terakhir ini hampir dapat dipastikan keliru karena teolog besar ini juga mempunyai paman atau kakek paman yang juga bernama al-Ghazali, seoarang sarjana terkemuka. Para penulis arab sering menyebutnya dengan nama ayahnya yakni Abu Hamid. ${ }^{21}$ Tapi bagaimanapun juga pengguna kata "al-Ghazali" lebih meluas dibanding "ghazzal". Nama al-Ghazali yang sebenarnya hanya Muhammad dan ia mempunyai saudara lelaki yang namanya Ahmad yang tercatat sebagai sufi dan menulis buku dalam bahasa persia. ${ }^{22}$

\footnotetext{
${ }^{14}$ Amalia, Sejarah Pemikiran Ekonomi Islam Klasik Hingga Kontemporer (Depok: Gramata Publising, 2010), 166.

15 Umer Chapra, Visi Islam dalam Membangun Ekonomi Menurut Maqhasid al-Syari'ah (Solo: al-Hambra, 2011), 21.

16 Syamsul Rijal, Bersama Imam Al-Ghazali Memahami Filosofi Alam Upaya Meneguhkan Keimanan (Yogyakarta: Ar-Ruzz, 2003), 50.

17 Tus adalah salah satu di antara kota-kota yang terkenal di Khurasan pada zaman dahulu. Saat itu Tus bukan lagi sebuah desa. Tus termasyhur karena hubungannya dengan penyair terkenal Firdausi yang meninggal di sana pada tahun 1020. Lihat Ibn al-Qayyum, Surat-Surat Al-Ghazali (Bandung: Mizan, 1988), 18.

${ }^{18}$ Sulaiman Dunya, Al-Haqiqat Pandangan Hidup Imam Al-Ghazali, terj. Ibnu Ali (Surabaya: Pustaka Hikmah Perdana, 2002), 36.

${ }^{19}$ Ibid., 18.

${ }^{20}$ Yunarsil Asril, Perkembangan Pemikiran Filsafat dalam Islam (Jakarta: Bumi Aksara, 1991), 67. Lihat juga Poerwantana, Seluk Beluk Filsafat Islam (Bandung: Rosdakarya, 1991), 166.

21 W. Montgomery Watt, Pemikiran dan Teologi dan Filsafat Islam, (Jakarta: P3M Penghimpunan Pengembangan Pesantren dan Masyarakat, t.th), 139.

22 Ibid.
} 
Dalam literatur Islam, al-Ghazali sering disebut juga sebagai Imam al-Ghazali. Dalam terminologi Sunni, istilah imam akan memberi pengertian yang berbeda dengan imam dalam Mazhab Syi'ah. Menurut aliran Sunni, imam Bukanlah masalah prinsip atau rukun dalam masalah agama, bukanlah jabatan sakral yang diwariskan secara turun menurun, terpeliharanya dari berbuat dosa besar maupun kecil (ma’șum). Imam dalam terminologi Sunni tidak lebih seorang muslim yang dikenal sangat istiqamah, memiliki ilmu yang luas, adil, takwa dan ahli dalam bidang agama. Ia sangat terampil dalam istinbat hukum dari sumber aslinya secara tegas, tepat dan akurat, atau dapat dibahasakan sebagai masalahmasalah agama, serta berani memberi fatwa agama jika memang dibutuhkan. ${ }^{23}$

Ayah al-Ghazali adalah seorang yang berbangsa persia yang bekerja sebagai pembuat pakaian dari benang bulu (ghazzal) dan menjualnya di pasar Tus. Beliau seorang fakir saleh yang senantiasa rendah hati serta seorang sufi yang tidak memakan kecuali dari hasil karya tangannya sendiri. Di waktu kosong, beliau suka mengaji ke salah seorang ulama dan duduk bersamanya. Lalu beliau memberikan pelayanan terbaik kepada ulama tersebut dan bersungguh-sungguh memperbaiki hubungan dengannya serta berinfak semampunya. Apabila mendengar nasehat dan wejangan khususnya dari ulama yang sering dikunjunginya, beliau selalu menangis dan berdoa kepada Allah agar anaknya dijadikan oleh Allah seorang yang alim dan dapat berdakwah.

Hanya saja, Allah berkehendak lain dan tidak memberinya kesempatan untuk menyaksikan apa yang menjadi harapannya. Namun demikian, harapannya tersebut dikabulkan dan doanya diterima oleh Allah dengan lahirnya al-Ghazali yang kemudian menjadi ulama besar dan pembela agama (hujjah al-Islam) dan hiasan agama (zayn al-din). ${ }^{24}$ Sang ayah meninggal dunia sewaktu al-Ghazali masih dalam keadaan belia. Para sejarawan tidak menyebutkan berapa usia al-Ghazali pada saat itu, hanya saja isyarat mereka menunjukkan bahwa saat itu pengarang Ihya- 'Ulüm al-Din ini masih kecil dan belum mencapai usia balig.

Sedangkan Ibu al-Ghazali, sejarah tidak pernah memberikan keterangan yang jelas sehingga penulis tidak menemukan data yang akurat untuk dijadikan referensi. Hampir semua buku yang membicarakan al-Ghazali tidak menyebutkan biografi ibu beliau secara jelas. Tetapi dapat dipastikan bahwa sang ibu sempat melihat dan menyaksikan anaknya pada jenjang karir yang tinggi sebagai ulama besar dan agung pada masanya. ${ }^{25}$

Al-Ghazzali mencapai tingkat kejayaan ilmu lebih karena merupakan hasil pendidikan yang terima baik secara formal maupun non formal. Karir pendidikannya dimulai dari seorang sufi yang merupakan sahabat ayahnya semasa hidup, yaitu Ahmad ibn Muhammad alRozkani. Melalui guru inilah, al-Ghazali banyak belajar tentang membaca dan menulis alQuran, Nahwu, Bahasa Arab, Ilmu hisab dan Fikih.

\footnotetext{
${ }^{23}$ M. Nazori Majid, Pemikiran Ekonomi Islam Abu Yusuf: Relevansinya dengan Ekonomi Kekinian (Yogyakarta: Pusat Studi Islam STIS, 2003), 21. Dalam terminologi Sunni, banyak kita temui beeberapa orang yang menyandang sebutan imam, namun yang paling populer dan dinobatkan sebagai imam dalam arti mujtahid adalah Imam Abu Hanifah, Imam Malik, Imam Shafi'i dan Imam Hambal.

${ }^{24}$ Nurcholis Majid, Khazanah Intelektual Islam (Jakarta: Bulan Bintang, 1984), 34.

${ }^{25}$ Sulaiman Dunya, Al-Haqiqat Pandangan Hidup, 39.
} 
Ketika berusia 15 tahun, pada tahun $456 \mathrm{H}$ al-Ghazali pindah ke Gurgan (Jurjan) ${ }^{26}$ di tenggara laut kaspi, berguru pada al-Syekh Abu Nasr Ismail Ibn Sa'adah al-Ismail Ibn Imam Ibn Bakr Ahmad Ibn Ibrahim al-Ismaili al-Jurjani. Selama di Jurjan beliau juga berguru pada Yusuf al-Nasaj dalam bidang tasawuf. Setelah lima tahun belajar di sana pada tahun $470 \mathrm{H}$, beliau pulang ke kampungnya dan tinggal di sana selama tiga tahun.

Tidak puas dengan apa yang diperoleh di Jurjan ia pergi ke Naysabur, ${ }^{27}$ sekitar $50 \mathrm{~km}$ dari Tus tempat kelahirannya untuk melanjutkan pelajaran ke tahap yang lebih tinggi. Ketika itu tahun $473 \mathrm{H}$ dan umurnya 23 tahun. Untuk mendalami berbagai disiplin ilmu antara lain filsafat, teologi, logika, tasawuf dan ilmu usul fikih pada seorang alim bernama Dhiya al-Din Abi al-Maali Al-Juwaini yang dikenal sebagai al-Imām al-Haramayn tahun $478 \mathrm{H}$.

Kehausan al-Ghazali akan ilmu pengetahuan sudah nampak sejak intelektualnya berkembang. ${ }^{28}$ Ia cenderung mengetahui, memahami dan mendalami masalah-masalah yang hakiki. Hal ini dilukiskan dalam kitab sejarah perkembangan pemikirannya, al-Ghazali berkata:

"Kehausanku untuk menggali hakekat segala persoalan telah menjadi kebiasaanku semenjak aku masih belia. Dan hal itu merupakan tabiat dan fitrah yang diletakkan Allah dalam kejadianku, bukan karena usahaku". ${ }^{29}$

Proses pendidikan al-Ghazali bermula dan wilayah kelahirannya di Tus kemudian berhijrah ke Jurjan lalu ke Nasyabur. Beliau telah mengikuti kurikulum pendidikan tinggi Islam secara sistematik dan standar sehingga mampu menampilkan beliau sebagai seorang tokoh ilmuan muslim yang masyhur pada zamannya dan buah dari keilmuannya dapat dirasakan hingga sekarang.

Setelah al-Juwaini wafat (tahun $478 \mathrm{H}$ atau $1085 \mathrm{M}$ ), al-Ghazali beranjak menuju ke markas Wazir Nidham al-Mulk (tahun 1063-1092 M), yang konon sering mengadakan aktivitas ilmiah, seperti bahth al-masail, diskusi dan musyawarah, yang biasanya diikuti oleh para ulama senior. Al-Ghazali sangat aktif mengikuti kegiatan ini. Penampilan al-Ghazali dalam aktivitas ini sangat mengagumkan, sehingga Nidham al-Mulk mengangkat si jenius ini sebagai dosen pada Universitas Nidhamiyah di Bagdad (484 H). Saat itu al-Ghazali baru berusia 27 tahun dan telah mendapatkan gelar terhormat di antara para sarjana-sarjana yang lain, sehingga pada tahun $1091 \mathrm{M}$ ia ditunjuk sebagai staf guru besar pada perguruan tinggi tersebut.

Di sinilah al-Ghazali Mulai mengukir sejarah sebagai tokoh ilmuwan yang akhirnya menjadi terkenal karena keilmuwannya serta kemahirannya dalam menegakkan kebenaran. Selama 4 tahun al-Ghazali menjadi guru besar yang sangat populer dangan jumlah siswa lebih dari 300. Pada saat yang bersamaan beliau telah menguasai filsafat al-Farabi dan Ibn Sina dengan jalan otodidak, suatu prestasi yang belum pernah dicapai oleh tokoh teolog manapun saat itu. Selain mengajar di sana selama 4 tahun, al-Ghazali juga aktif meneliti ajaran dan

\footnotetext{
${ }^{26}$ Jurjan adalah kota terletak antara Thabarista dan Khurasan yang dibangun oleh Yazid ibn Mahlab.

${ }^{27}$ Nasyabur adalah kota Khurasan, kota terbesar abad pertengahan. Kota ini banyak melahirkan tokoh-tokoh kenamaan, seperti Umar Kayyam seorang pujangga besar.

${ }^{28}$ Abidin Ibn Rusn, Pemikiran Al-Ghazali tentang Pendidikan (Yogyakarta: Pustaka Pelajar, 1998), 11.

${ }^{29}$ Al-Ghazali, al-Munkidh Min al-Ḍalal (Istanbul: Dār al-Safeka, 1981), 4.
} 
aliran yang berkembang dari berbagai jenis pengetahuan sampai muncul keraguan pada dirinya. ${ }^{30}$

Di balik fenomena yang luar biasa atas keberhasilannya, ia mengalami penderitaan yaitu merasakan bahaya besar api neraka. Pada tahun 1095 M konflik batinnya menngakibatkan gejala sakit fisik berupa ganguan dalam berbicara sehingga al-Ghazali tidak dapat lagi mengajar. Agar tidak ada yang menghalangi kepergiannya baik dari penguasa maupun sahabatnya di Universitas Nidhamiyah, akhirnya secara diam-diam ia pergi ke Syam. AlGhazali berdalih pergi ke Makkah untuk menunaikan ibadah haji. Seusai ibadah haji beliau menuju ke Damaskus, Syria (sekitar tahun 489 H). Setelah bermukim di Damaskus ${ }^{31}$ selama 2 tahun, ia mengasingkan diri dan berdiam diri di masjid. ${ }^{32}$ Setelah bersafari selam 10 tahun diawali dari palestina, Syiria, dan Hijaz beliau berhijrah ke Kairo, Mesir dan selanjutnya ke Iskandariyah. Kemudian kembali lagi ke Naysabur untuk melanjutkan kegiatannya mengajar di Nidhamiyah.

Pada akhir tahun 1104 M, saat terjadi pergantian penguasa Dinasti Saljuk, kedudukan perdana mentri dipegang oleh salah satu putra Nidham Al-Mulk. Sosok inilah yang mempengaruhi al-Ghazali untuk kembali pada kehidupan akademik dan mengajar di perguruan tinggi Nidham Al-Mulk. Salah satu yang menjadi pertimbangan kembalinya alGhazali Saat itu adalah ungkapan Rasulullah SAW bahwa pada awal setiap abad akan muncul seorang pemburu keagamaan. Saat itu merupakan akhir abad ke-5 H, dan banyak temanteman al-Ghazali meyakinkan bahwa dialah yang ditakdirkan menjadi pemburu keagamaan pada abad berikutnya. ${ }^{33}$ Maka ia pun pergi ke Nasyabur oleh putra Nizham al-Mulk. Di sinilah beliau mengarang kitab al-Munkidh min al-Dalal (501-502 H). Secara umum buku ini berisi tentang bagaimana seseorang mencari kebenaran, ${ }^{34}$ semacam otobiografi yang memuat perkembangan intelektual dan spiritual pribadinya, di samping penilainnya terhadap metode para pemburu kebenaran, macam-macam ilmu pengetahuan dan epistimologinya. Empat tahun kemudian al-Ghazali kembali lagi ke kampung halamannya, Tus. Di sinilah ia menggagas sebuah madrasah bagi ahli-ahli fikih dan sebuah halaqah bagi kaum sufi yang berdekatan dengan rumahnya. Sejak itu aktivitas beliau adalah sibuk mengarang, memberi ceramah dan menyebarkan ilmu pengetahuannya dengan cara masuk kampung dan keluar kampung. Akhirnya dua tahun kemudian tepatnya hari Senin 14 jumadil Akhir $505 \mathrm{H}^{35}$ atau 18 Desember $1111^{36}$, al-Ghazali meninggal dunia pada usia 55 tahun $^{37}$ dengan meninggalkan beberapa anak perempuan dan buah karya yang berguna. Ia dimakamkan di makam Thabaran berdekatan dengan makam penyair parsi yang mashur bernama al- Firdausi.

\footnotetext{
${ }^{30}$ Keraguan pada dirinya karena mempertanyakan akal (intelektual). Lihat Syamsul Rijal, Bersama Imam AlGhazali, 51.

${ }^{31}$ Di damaskus inilah Al-Ghazali menulis kitab Ihyà 'Ulum al-Dīn di menara masjid dan beberapa kitab lainnya. Lihat Ibnu al-Qayyum, Surat-surat Al-Ghazali, 9.

${ }^{32}$ Al-Ghazali, al-Munkidh Min al-Dalal, 8.

${ }^{33}$ W. Montgomomery Watt, Kejayaan Islam Kajian Kritis dari Tokoh Orientalis (Yogyakarta: Tiara Wacana, 1990), 141.

${ }^{34}$ Yang dimaksud dengan "pencari kebenaran” adalah empat golongan, yaitu golongan teolog; golongan filosof; golongan Ismailiyah; dan golongan sufi. Lihat Ibid., 141.

${ }^{35}$ Ibid., 260.

${ }^{36}$ A. Hanafi, Pengantar Filsafat Islam (Jakarta: Bulan Bintang, 1976), 198.

${ }^{37}$ Abu Hasan al-Nadwi, Rijal al Fikr wa al-Da'wah fi al-Isläm (Kuwait: Dār al-Qalam, 1969), 203-205.
} 
Sebagai pemikir Islam, al-Ghazali sangat produktif dalam menulis. Hal ini dapat dilihat dalam karya-karyanya yang dapat dikategorikan sebagai respon langsung terhadap sejumlah problem krusial di masanya. Karya-karya yang ditulis al-Ghazali sangat bervariasi sesuai dengan perkembangan ilmu pada zamannya. Di antaranya meliputi bidang fikih, ilmu kalam, mantik, tasawuf, filsafat, dan lain-lain. ${ }^{38}$

Tokoh al-Ghazali ini cukup mempunyai nama besar pada hidupnya. Hal ini tidak hanya dikarenakan corak berfikirnya yang maju, tapi beliau juga seorang tokoh yang paling banyak kebijakannya dalam kehidupan bermasyarakat dan bernegara pada masa itu. Selain itu, posisi sebagai tokoh ilmuawan yang brilian dan selalu mencari hakikat kebenaran ada di pundaknya. Hal ini dapt dilihat dari banyaknya karya ilmiah dan tulisan yang merespon gejala tatanan sosial dan agama, sehingga tidaklah begitu mengherankan dengan reputasi baik tersebut beliau mendapat kehormatan untuk memimpin Universitas Nidhamiyah.

\section{Pemikiran Al-Ghazali Tentang Mekanisme Pasar}

Mekanisme pasar adalah sebuah sistem yang menentukan terbentuknya harga, yang di dalam prosesnya dapat dipengaruhi oleh berbagai hal di antaranya adalah permintaan dan penawaran, distribusi, kebijakan pemerintah, pekerja, uang, pajak dan keamanan. ${ }^{39}$ Dalam proses mekanisme pasar tersebut diharuskan adanya asas moralitas, antara lain persaingan yang sehat (fairplay), kejujuran (honesty), keterbukaan (transparancy), dan keadilan (justice).

Sepanjang tulisannya, al-Ghazali berbicara mengenai harga yang berlaku seperti yang ditentukan oleh praktek-praktek pasar, sebuah konsep yang dikemudian hari dikenal sebagai al-thaman al- 'ádil (harga yang adil) di kalangan ilmuan muslim atau equilibrium price (harga keseimbangan) di kalangan ilmuan Eropa kontemporer). ${ }^{40}$ Sebagai akibat dari mekanisme pasar yang terbuka yang telah digambarkan oleh al-Ghazali, telah memberikan bagi masyarakat luas untuk ambil bagian dalam menentukan harga. Dalam ekonomi Islam wujud pasar merupakan refleksi dari kemampuan masyarakat dalam memenuhi kebutuhankebutuhannya. ${ }^{41}$

Walaupun al-Ghazali tidak menjelaskan konsep permintaan dan penawaran dalam terminologi modern, namun beberapa paragraf tulisannya menunjukkan konsep penawaran dan permintaan. Menurutnya, untuk kurva penawaran "naik dari kiri ke bawah ke kanan atas" dinyatakan sebagai "jika petani tidak mendapatkan pembeli barangnya, maka ia akan menjualnya dengan harga murah". ${ }^{42}$ Sementara untuk kurva permintaan yang "turun dari kiri kanan atas kanan bawah" dijelaskan oleh beliau sebagai "harga dapat diturunkan dengan mengurangi permintaan". ${ }^{43}$

Suatu hal yang mengejutkan bahwa al-Ghazali juga memahami konsep elastisitas permintaan, yaitu mengurangi margin keuntungan dengan menjual pada harga yang lebih murah akan meningkatkan volume penjualan dan ini pada gilirannya akan meningkatkan

\footnotetext{
${ }^{38}$ Harun Nasution, Islam Ditinjau Berbagai Aspeknya (Jakarta: UII Press, 1985), 54.

${ }^{39}$ P3EI, Ekonomi Islam (Jakarta: Rajawali Press, 2012), 301-345.

${ }^{40}$ Adiwarman A. Karim, Sejarah Pemikiran Ekonomi Islam (Jakarta: Rajawali Press, 2010), 325.

${ }^{41}$ Heri Sudarsono, Konsep Ekonomi Islam Sebuah Pengantar (Yogyakarta: UII Press, 2002), 21.

${ }^{42}$ Abu Hamid al-Ghazali, Ihyā' 'Ulūm al-Dìn, Jilid 3 (Bairut: Dār al-Kutub al-Islāmiyyah, 2005), 227.

${ }^{43}$ Ibid.
} 
keuntungan, ${ }^{44}$ bahkan ia telah pula mengindentifikasikan produk makanan sebagai komoditas dengan kurva permintaan yang inelsatis, karena makanan adalah kebutuhan pokok, perdagangan makanan harus seminimal mungkin didorong oleh motif mencari keuntungan semacam ini, sayogyanya dicari dari barang-barang kebutuhan pokok. ${ }^{45}$

Seperti halnya pemikir lain pada masanya, al-Ghazali setelah berbicara konsep permintaan (demand) dan penawaran (suply), juga membicarakan harga yang langsung dikaitkan dengan keuntungan-keuntungan, yaitu kompensasi dari kepayahan perjalanan, resiko bisnis dan ancaman keselamatan diri sepedagang. ${ }^{46}$ Al-Ghazali tidak setuju dengan keuntungan berlebihan untuk menjadi motivasi berdagang. Bagi al-Ghazali, keuntungan yang sesungguhnya adalah keuntungan akhirat kelak. ${ }^{47}$

Al-Ghazali, sebagaimana ilmuwan muslim lainya dalam membicarakan harga selalu mengaitkan dengan keuntungan. Dia belum mengaitkan harga barang dengan pendapatan dan biaya-biaya. Bagi al-Ghazali, keuntungan (ribh), merupakan kompensasi dari kesulitan perjalanan, resiko bisnis dan ancaman keselamatan si pedagang. ${ }^{48}$ Meskipun al-Ghazali menyebut keuntungan dalam tulisannya tetapi kita bisa paham bahwa yang dimaksudkannya adalah harga. Artinya, harga bisa dipengaruhi oleh keamanan perjalanan, resiko dan sebagainya. Perjalanan yang aman akan mendorong masuknya barang impor dan menimbulkan peningkatan penawaran, akibatnya harga menjadi turun, demikian pula sebaliknya.

Al-Ghazali dalam Ihya', 'Ulüm al-Dīn, juga telah membahas secara detail peranan aktivitas perdagangan dan timbulnya pasar yang harganya bergerak sesuai dengan kekuatan penawaran dan permintaan. Menurutnya, pasar merupakan bagian dari keteraturan alami. Beberapa paragraf dari tulisannya jelas menunjukkan bentuk kurva penawaran dan permintaan. Untuk kurva penawaran "yang naik dari kiri bawah ke kanan atas" dinyatakan dalam kalimat "jika petani tidak mendapatkan pembeli barangnya, maka ia akan menjualnya pada harga yang murah. ${ }^{49}$ Sementara untuk kurva pemintaan "yang turun dari atas ke kanan bawah" dijelaskan dengan kalimat "harga dapat diturunkan dengan mengurangi permintaan". 50

Mengenai konsep keuntungan dalam Islam, al-Ghazali mengatakan bahwa motif berdagang adalah mencari kuntungan. Tetapi ia tidak setuju dengan keuntungan yang besar sebagai motif berdagang, sebagaimana yang diajarkan kapitalisme. AL-Ghazali dengan tegas menyebutkan bahwa keuntungan bisnis yang ingin dicapai seorang pedagang adalah keuntungan dunia akhirat, bukan keuntungan dunia saja. Yang dimaksud keuntungan akhirat adalah pertama, harga yang dipatok si penjual tidak boleh berlipat ganda dari modal, sehingga memberatkan konsumen. Kedua, berdagang adalah bagian dari realisasi ta'äwun (tolong menolong) yang dianjurkan Islam. Pedagang mendapat keuntungan sedangkan konsumen

\footnotetext{
${ }^{44}$ Abu Hamid al-Ghazali, Ihyā' 'Ulūm al-Dīn, Jilid 2 (Bairut: Dār al-Kutub al-Islāmiyyah, 2005), 132.

45 Ibid.

${ }^{46}$ Abu Hamid al-Ghazali, Ihyà 'Ulūm al-Dìn, Jilid 4 (Bairut: Dār al-Kutub al-Islāmiyyah, 2005), 116.

${ }^{47}$ Abu Hamid al-Ghazali, Ihya' 'Ulüm al-Dīn, Jilid 2 (Bairut: Dār al-Kutub al-Islāmiyyah, 2005), 75-78.

${ }^{48}$ Abu Hamid al-Ghazali, Ihyā' 'Ulūm al-Dìn, Jilid 4 (Bairut: Dār al-Kutub al-Islāmiyyah, 2005), 10.

${ }^{49}$ Abu Hamid al-Ghazali, Ihyā' 'Ulūm al-Dìn, Jilid 3 (Bairut: Dār al-Kutub al-Islāmiyyah, 2005), 227.

${ }^{50}$ Abu Hamid al-Ghazali, Ihyā' 'Ulūm al-Dìn, Jilid 3 (Bairut: Dār al-Kutub al-Islāmiyyah, 2005),73.
} 
mendapatkan kebutuhan yang diinginkan. Ketiga, berdagang dengan mematuhi etika ekonomi Islam merupakan aplikasi syariah, maka ia dinilai sebagai ibadah.

Terkait kedudukan pemerintah, al-Ghazali berpendapat bahwa keberadaan pemerintah merupakan institusi yang sangat dibutuhkan, terutama dalam bidang perekonomian. Dasar pemerintahan dalam perekonomian yang dipakai al-Ghazali terlihat pada pendapatnya tentang mengenai dibutuhkannya sebuah negara. Menurut al-Ghazali, negara merupakan suatu lembaga yang demikian penting karena ia adalah suatu bentuk pergaulan hidup manusia yang mengantarkan kepada kebahagian hakiki. Dalam mewujudkan hal itu, maka negara sangat diperlukan. Secara tegas al-Ghazali menyatakan bahwa agama (al-din) merupakan pokok (fondasi) sebuah bangunan, sedang negara adalah penjaganya. Setiap bangunan tanpa fondasi akan tumbang, begitu juga bangunan tampa adanya penyangga akan sia-sia. ${ }^{51}$

Negara itu mempunyai prasyarat tertentu, yaitu mempunyai daerah tertentu, rakyat tertentu, dan mempunyai pemerintahan. ${ }^{52}$ Artinya negara tidak bisa berdiri sendiri. Dari sini maka timbul pertanyaan dari mana asal mula negara?. Al-Ghazali berpendapat bahwa manusia adalah makhluk sosial, diciptakan oleh Allah tidak untuk sendirian, tetapi selalu membutuhkan pihak lain untuk hidup bersama. Manusia tidak dapat hidup sendirian paling tidak disebabkan oleh dua faktor, yaitu kebutuhan akan keturunan (al-nasl) demi kelangsungan hidup umat manusia, dan saling membantu (al-ta'āwun).

Untuk mempertahankan keutuhan negara dan menjamin keberlangsungannya, alGhazali menganjurkan kepada rakyat untuk mentaati pemerintah dan pemerintah wajib untuk menciptakan keadilan. Tujuan utama pemegang otoritas adalah untuk mengatur rakyatnya dangan adil dan lebih mengutamakan kebaikan urusan publik. Adapun salah satu aspek yang penting dari keadilan adalah adanya pejabat yang baik dan mampu memelihara kesejahteraan spiritual dan material. Menurut bahasa al-Ghazali, yang menjadi sumber-sumber aturan adalah ketuhanan (al-hadarah al-rububiyyah), karena ia merupakan tempat segala kebaikan, keindahan dan tumbuhnya segala ketertiban dan pengaturan (undang-undang). ${ }^{53}$

Al-Ghazali sangat menghormati keadilan sebagai sesuatu yang fundamental dan krusial. Tanpa kondisi keadilan dan kebaikan dan niscaya manusia tidak bisa mencapai kehidupan yang layak baik dunia maupun di akhirat. Walaupun tidak menggunakan terminologi modern, al-Ghazali telah mengidentifikasi dengan jelas berbagai jenis dan fungsi ekonomi yang dijalankan oleh negara. Ia menitikberatkan bahwa untuk meningkatkan kemakmuran ekonomi, negara harus menegakkan keadilan, kedamaian, dan keamanan, serta stabilitas. Ia menekankan perlunya keadilan, serta peraturan yang adil dan seimbang. ${ }^{54}$

Dengan demikian, tampak jelas bahwa bagi al-Ghazali negara bertanggung jawab dalam menciptakan kondisi yang layak untuk meningkatkan kemakmuran dan pembangunan ekonomi. Dan al-Ghazali memahami pembagian tugas (job discription) dalam pelaksanaan tugas negara. Ia memberikan perumpamaan seorang tentara tidak boleh terlibat dalam bidang industri, walaupun di sana ia dibutuhkan dalam pengawasan, tau sebaliknya. Di samping itu, al-Ghazali juga menulis panjang lebar dalam kitab Ihya' 'Ulum al-Din pada bab “al-amr bi al-

\footnotetext{
${ }^{51}$ Abu Hamid al-Ghazali, al-Iqtiṣād fī al-I’tiqād (Libanon: Dār al-Kutub al-'Ilmiyyah, 1988), 149.

${ }^{52}$ Abdul Rojak, Politik Kenegaraan: Pemikiran-Pemikiran Al-Ghazali dan Ibnu Taimiyah (Surabaya: Bina Ilmu, 1999), 95.

53 Ibid.

${ }^{54}$ Abu Hamid al-Ghazali, Ihyā' 'Ulūm al-Dīn, Jilid 3 (Bairut: Dār al-Kutub al-Islāmiyyah, 2005), 221.
} 
ma'rüf wa al-nahy 'an al-munkar" mengenai Lembaga Hisbah, yaitu sebuah badan pengawas yang dipakai banyak negara Islam pada waktu itu. Fungsi badan ini adalah mengawasi praktek-praktek pasar yang merugikan. ${ }^{55}$

Dalam terminologi ekonomi, keadilan dari penguasa berarti penguasa akan meminta dari masyarakat agar benar-benar sesuai dengan keadilan, misalnya pembayaran pajak. Penduduk sebaiknya segera membayar pajak tersebut tanpa berusaha untuk mengelak. AlGhazali menyatakan bahwa sebagian besar ketidakadilan itu dilakukan oleh dua pihak, penguasa dan warga negara (masyarakat), yaitu dalam hal penguasa menginginkan sesuatu yang tak ada kewenangannya sementara yang warga negara berusaha mengingkari meskipun tahu itu wajib dilaksanakannya. Kebijakan yang adil adalah jika penguasa memberikan ganjaran kepada siapa saja yang memang berhak. Sebaliknya penduduk tidak akan meminta yang bukan haknya.

Peran sebuah negara dalam kehidupan ekonomi menurut al-Ghazali adalah sebagai konsep dasar negara kesejahteraan. Suatu negara tidak akan mengabaikan peranan institusi yang berkewajiban dalam pengawasan pasar. Institusi inilah yang dinamakan dengan Lembaga Hisbah. Lembaga ini boleh dikembangkan terlebih dalam kegiatan ekonomi karena tugas utama lembaga ini adalah al-amr bi al-ma'rúf wa al-nahy 'an al-munkar, maka kewajiban ini merupakan salah satu kewajiban fundamental, karen terkait dengan kelangsungan sebuah misi universal Islam. Al-Ghazali menyebut al-amr bi al-ma'rüf wa alnahy 'an al-munkar adalah pokok dari agama.

Secara normatif tugas al-amr bi al-ma'rüf wa al-nahy 'an al-munkar terutama harus dilakukan oleh aparat negara dan atau orang-orang yang berkompeten di dalamya. Karena itu muncullah Lembaga Hisbah yang merupakan institusi negara yang secara umum bertugas melaksanakan al-amr bi al-ma'rüf wa al-nahy 'an al-munkar. Negara diberi wewenang untuk melembagakan institusi ini agar tercipta tatanan kemasyarakatan yang patuh terhadap hukum publik. ${ }^{56}$ Pelaksanaan tugas ini pada akhirnya akan membawa suatu negara meraih posisi baldah tayyibah sebagaimana diilustrasikan al-Quran. ${ }^{57}$ Oleh karena itu, diperlukan petugas resmi yang diangkat oleh negara untuk melaksanakan tugas berat dan mulia ini. Dalam kajian fiqh al-siyasah, petugas resmi tersebut dinamakan muhtasib. ${ }^{58}$

\section{Kesimpulan}

Konsep pemikiran tentang mekanisme pasar khususnya pada faktor-faktor yang mempengaruhinya, al-Ghazali melandaskan bahwa teori harga dalam mekanisme pasar disebabkan oleh adanya hukum permintaan dan penawaran. Untuk tugas pemerintah, alGhazali menjelaskan bahwa pemerintah bertugas untuk mengawasi pasar demi terciptanya keadilan dan pasar bebas. Penetapan harga menurut al-Ghazali mencapai mașlahah hajjiyyah, yaitu segala sesuatu yang menjadikan nyaman setelah kebutuhannya terpenuhi semuanya. Apabila konsumen memiliki anggaran dana yang lebih dan setelah kebutuhannya pokoknya

\footnotetext{
${ }^{55}$ Abdur Rohman, Ekonomi Al-Ghazali (Surabaya: PT. Bina Ilmu, 2010), 161.

56 Jhon L. Esposito, The Oxford Encyclopedia of the Modern Islamic World, Vol. 2 (New York: Oxford University Press, 1995), 113-114.

${ }^{57}$ Muhammad Dhiya' al-Din al-Ris, al-Nadzariyyah al-Siyāsah al-Islämiyyah (Kairo: Maktabah Dār al-Turāth, 1979), 315.

58 Abdur Rohman, Ekonomi Al-Ghazali, 178.
} 
terpenuhi maka perlu kiranya kebutuhan yang membuatnya senang dan nyaman karena dapat menambah kualitas ibadah dan mempermudah kinerjanya.

Negara sejatinya bersikap sebagai wasit atau pengadil dalam transaksi ekonomi masyarakatnya dan itu dapat dilihat dari diperlukannya Lembaga Hisbah yang bertugas untuk mengawasi keadaan dalam pasar sekaligus berhak menjatuhkan hukuman apabila diduga terjadi kecurangan di dalam pasar.

\section{Daftar Rujukan}

al-Ghazali, Abu Hamid. al-Iqtiṣād fī al-I’tiqād. Libanon: Dār al-Kutub al-'Ilmiyyah, 1988. . al-Munkidh Min al-Ḍalal. Istambul: Dār al-Safeka, 1981. Ihyā' Ulüm al-dīn. Beirut: Dār al-Kutub al-Islāmiyyah, 2005.

al-Nadwi, Abu Hasan. Rijal al Fikr wa al-Da'wah fi al-Islām. Kuwait: Dār al-Qalam, 1969.

al-Ris, Muhammad Dhiya' al-Din. al-Nadzariyyah al-Siyāsah al-Islämiyyah. Kairo: Maktabah Dār al-Turāth, 1979.

Amalia. Sejarah Pemikiran Ekonomi Islam Klasik Hingga Kontemporer. Depok: Gramata Publising, 2010.

Asril, Yunarsil. Perkembangan Pemikiran Filsafat dalam Islam. Jakarta: Bumi Aksara, 1991. Chamid, Nur. Jejak Langkah Sejarah Pemikiran Ekonomi. Yogyakarta: Pustaka Pelajar, 2010. Chapra, Umer. Visi Islam dalam Membangun Ekonomi Menurut Maqhasid al-Syari'ah. Solo: al-Hambra, 2011.

Daudi, Ahmad. Kuliah Filsafat Islam. Jakarta: Bulan Bintang, 1986.

Deliarnov. Perkembangan Pemikiran Ekonomi. Jakarta: Raja Grafindo Persada, 1997.

Departemen Agama RI. Al-Qur'an dan Terjemahan. Solo: PT Tiga Serangkai, 2009.

Dunya, Sulaiman. Al-Haqiqat Pandangan Hidup Imam Al-Ghazali, terj. Ibnu Ali. Surabaya: Pustaka Hikmah, 2002.

Esposito, Jhon L. The Oxford Encyclopedia of the Modern Islamic World. New York: Oxford University Press, 1995.

Hanafi, A. Pengantar Filsafat Islam. Jakarta: Bulan Bintang, 1976.

Hendrianto. Pengantar Ekonomi Mikro Islami. Yogyakarta: Ekonisia, 2003.

Hidayat, Mohamad. an Introduction to The Sharia Economic. Jakarta: Zikrul Hakim, 2010.

Karim, Adiwarman Azwar. Sejarah Pemikiran Ekonomi Islam. Jakarta: Rajawali Press, 2010.

Lubis, Suhrawardi K. Hukum Ekonomi Islam. Jakarta: Sinar Grafika, 2000.

Madjid, Nurcholis. Khazanah Intelektual Islam. Jakarta: Bulan Bintang, 1984.

Majid, M. Nazori. Pemikiran Ekonomi Islam Abu Yusuf: Relevansinya dengan Ekonomi Kekinian. Yogyakarta: Pusat Studi Islam STIS, 2003.

Mannan, Abdul. Teori dan Praktek Ekonomi Islam, terj. M. Nastangin. Yogyakarta: PT Dana Bakti Wakaf, 1997.

Nasution, Harun. Islam Ditinjau Berbagai Aspeknya. Jakarta: UII Press, 1985.

Poerwantana. Seluk Beluk Filsafat Islam. Bandung: Rosdakarya, 1991.

Rahman, Abdur. Ekonomi Al-Ghazali. Surabaya: PT Bina Ilmu, 2010.

Rizal, Syamsul. Bersama Imam Al-Ghazali Memahami Filosofi Alam, Upaya Meneguhkan Keimanan. Yogyakarta: Ar-Ruzz, 2003.

Rojak, Abdul. Politik Kenegaraan, Pemikiran-Pemikiran Al-Ghazali dan Ibnu Taimiyah. 
Surabaya: Bina Ilmu, 1999.

Rusn, Abidin Ibnu. Pemikiran Al-Ghazali tentang Pendidikan. Yogyakarta: Pustaka Pelajar, 1998.

Soule, George. Pemikiran Para Pakar Ekonomi Terkemuka. Yogyakarta: Kanisius, 1994.

Sudarsono, Heri. Konsep Ekonomi Islam Sebuah Pengantar. Yogyakarta: UII Press, 2002.

Watt, W. Montgomomery. Kejayaan Islam Kajian Kritis dari Tokoh Orientalis. Yogyakarta: Tiara Wacana, 1990.

- Pemikiran dan Teologi dan Filsafat Islam. Jakarta: P3M Penghimpunan Pengembangan Pesantren dan Masyarakat, t.th. 